\title{
Childless Women's Relationships with Children of Others: Narratives from Two Generations in Lithuania
}

\author{
Lina Šumskaitė and Margarita Gedvilaitė-Kordušienė
}

\begin{abstract}
A childless woman who lives in a society with pronatalist values can be in a vulnerable position. In 2006, only $1.9 \%$ of Lithuanians expressed positive attitudes about childlessness, and $84.6 \%$ valued it negatively (Stakuniene and Maslauskaite 2008), signalling the pronatalist tendency of Lithuanian society. However, some studies confirm a shift from traditional to more individualistic familial attitudes (Kanopienè et al. 2015). This chapter investigates the relationship between childless women from two generations in Lithuania and the children of these women's relatives or friends. The analysis is based on 40 semi-structured qualitative interviews conducted in 2017-2018 with single and coupled women between the ages of 28 and 71 who are voluntarily and involuntarily childless. The women of reproductive age were considering their intentions to have or not have children in the future, and some were going through infertility treatments; women over 50 reflected on permanent childlessness. Most of the interviewed women were involved in taking care of their siblings' or close relatives' children during a period in their lives, and in some cases, these women became substitute parents. Only a few women stated that they avoided contact with children in their personal lives.
\end{abstract}

Keywords Childless and childfree women · Relationships with children · Qualitative methodology · Lithuania

The original version of this chapter was revised: The chapter was inadvertently published excluding an Acknowledgement which has been added now. The correction to this chapter can be found at https://doi.org/10.1007/978-981-16-0792-9_14

\author{
L. Šumskaitè $(\bowtie)$ \\ Vilnius University, Vilnius, Lithuania \\ M. Gedvilaitè-Kordušienè \\ Institute of Sociology, Lithuanian Centre for Social Sciences, Vilnius, Lithuania
}

(C) The Author(s), under exclusive license to Springer Nature

Singapore Pte Ltd. 2021, corrected publication 2022

H. Wahlström Henriksson, K. Goedecke (eds.), Close Relations, Crossroads of Knowledge, https://doi.org/10.1007/978-981-16-0792-9_11 


\section{Introduction}

Pronatalism, ideas and attitudes that encourage procreation, is a prevailing characteristic in most societies. Pronatalism is predominant enough that it might be framed as 'a collection of beliefs so embedded that they have come to be seen as true', and it has a particular impact on women: 'a cardinal premise in pronatalist thought is the supposition that a woman's role must involve maternity' (Carrol 2012 in Venkatesan and Murali 2019, 2). Since women's social identities are strongly linked to motherhood, childless women are often perceived as 'others' in pronatalist societies (Venkatesan and Murali 2019). Melissa Graham et al. (2013) refer to a number of research studies in Western societies that confirm that women without children continue to be stigmatized, negatively stereotyped and even socially excluded.

Pronatalist attitudes that form the child-centred discourse are particularly prevalent in societies with low fertility rates. Lithuania has experienced a fertility decline since 1991, with moderate fluctuations below population replacement levels, and the country stands out in the European context with its less positive attitude regarding childlessness. In 2006 only $1.9 \%$ of Lithuanians expressed positive attitudes toward childlessness, while $84.6 \%$ valued it negatively (Stakuniene and Maslauskaite 2008). Along with other Eastern European countries (Estonia, Hungary, Latvia, Poland, Romania, Russia, Slovenia, Slovakia, and Ukraine), Lithuanians express more traditional family norms and less approval of voluntary childlessness. In contrast, Western European countries (Austria, Belgium, Switzerland, Cyprus, Germany, Denmark, Ireland, the Netherlands, Norway, Portugal and Sweden), pioneers in the Second Demographic Transition, value autonomy, emancipation and modernization, and these values are linked to a higher approval of voluntary childlessness (Stakuniene and Maslauskaite 2008; Merz and Liefbroer 2012). Less acceptance of different life courses in Lithuania creates a cultural context in which, despite more individualistic attitudes, the narratives of stigmatization and social exclusion still can be detected. A qualitative comparative study of experiences of childlessness in Lithuania and Poland reveals how the dominant social discourse leads to feelings of exclusion from certain social circles (work and religious communities, friends) and induces a sense of otherness (Gedvilaitė-Kordušienè et al. 2020).

We use the concepts of 'childlessness' and 'childfreeness' as synonyms in the text, both referring to the absence of biological children. Even if the term childfree does not hold the connotation of lack, present in the term childless (Gibb 2019), some authors acknowledge that both of these terms could be understood as negative in the public discourse: 'childless' signifies those who are unable to reproduce and, hence, are considered 'incomplete', 'not whole', with 'something missing'; whereas 'childfree' women sometimes are framed as 'selfish' and 'crazy' for choosing not to have children (Venkatesan and Murali 2019, 14-15). Despite the sexist and misogynous overtones of these expressions, we have decided to use them to describe the women in our study; those who described their experiences of childlessness in terms of 'something missing' or stated that it would be nice to have children are referred 
as childless in the text. 'Childfree' is used to define women who expressed an active decision not to have children at the moment of the interview and in the future. We use the term 'childfree attitudes' to describe women's positions towards childbearing when women questioned the necessity of children in their lives. Some women in our sample have not made active choices to stay childfree during their reproductive lives; however, their narratives expressed childfree positions, which we consider as 'childfree attitudes'.

Though the literature on various aspects of childlessness is increasing, most studies have concentrated on what childless people lack or need in terms of support (Albertini and Kohli 2009). Focusing on childless women's communication with other people's children, this article fits into the emerging field exploring what women with no children give to their families, friends and society. Among the few studies that include childless women's relationships with children, it was found that childless women still do parenting work, especially single women without bachelor's degrees (Martin and Kendig 2012). Yet the ways that childless women communicate with other people's children is still an unresearched area. Based on qualitative research with two generations of childless women in Lithuania, in the following analysis, we explore the relationships of childless women with other people's children. We argue that childless and childfree women's relationships with kin and non-kin children reveal a shift towards individualization: from 'necessity' and 'duty' towards 'choices' about when and how to nurture and maintain relationships with children.

\section{Individualization Theory and Flows of Care Between Childless Women and Kin Children}

Individualization theory claims that social and family relationships have become increasingly dependent on individualized choice (Giddens 1991; Beck 1993). Compared to 'tradition societies', structured by traditional institutions and norms, life in 'modern societies' has become increasingly depended on the individual and their choice. Individualization theory is often used to explain the observed decline in total fertility rates as well as the increasing choice to be childfree (Van De Kaa 1996). If women born between the two world wars ended up childless because of never marrying or marrying late, these women usually see childlessness as a fate, rather than the result of making a conscious decision not to have children (Dykstra and Hagestad 2007). However, generations born in the second half of the twentieth century are described as having greater autonomy and individualism (Giddens 1991; Beck and Beck-Gernsheim 2002), and voluntary childlessness is reported as a phenomenon of younger generations.

Based on individualization theory, there is no obvious reason why childless individuals should invest in the relationships with their kin (Pollet et al. 2006). However, quantitative studies suggest childlessness can affect the likelihood of giving and 
receiving help from kin, even in modern societies (Pollet et al. 2006). Some studies in European societies analysing support flows within familial dyads found that childless individuals give a substantial amount of support. For example, Marco Albertini and Martin Kohli $(2009,1272)$ found that older childless individuals in European countries provide a significant amount of support for other people but have more diverse support networks compared to parents: 'While parents' exchanges are often limited to parent-child relations, people without children establish stronger links with kin from the ascendant and their own generation and with nonrelatives'. The authors also find evidence that the childless people tend to give more support to the society than parents through voluntary and charitable work. Similarly, a study in Finland reveals that childless women are more likely than mothers to invest in their nieces and nephews (Tanskanen 2015). The author explains this tendency in the framework of the reproductive value hypothesis, arguing that individuals may increase their fitness more by investing in their kin in descending rather than ascending order. Based on a qualitative study in Belgium, Thomas V. Pollet and Robin Dunbar argue that childless couples invest more in their nieces and nephews than couples who have children, as the latter are occupied with their own children and do not care about children of other people as much (Pollet and Dunbar 2008).

Alexander Pashos and Donald H. McBruney (2008) found that aunts are more caring than uncles in the U.S. Youngest or last-born maternal aunts are likely to take care of their nieces and nephews. The authors explain that younger sisters usually do not have their own children while they help their older sisters. In that way, they learn nurturing behaviour, which can be useful later when they give birth. They also can assume that taking care of other children in the extended family requires less energy than having their own (Pashos and McBurney 2008). However, others found educational differences in the behaviour patterns of childless women in the United States: highly educated, single childless women seldom spend time with other people's children, but childless women with less education do parenting work more often (Martin and Kendig 2012). The authors found that the marital status and education of the childless women affect the time spent with other people's children.

Qualitative studies (Wirtberg et al. 2007; Ferland and Caron 2013) on long-term consequences of unsuccessful fertility treatments show that the interviewed women searched for activities that could fulfil their desire to nurture. Some women looked after siblings' children or friends' children and bonded with them in close relationships. Other women volunteered with children, for example, at Sunday school. Taking care of older parents was described as a nurturing activity as well. The motivation to take care of somebody was often explained by the women as not being too self-centred (Wirtberg et al. 2007). 


\section{Lithuanian Historical and Socio-cultural Contexts of Childlessness}

Female emancipation in Eastern European countries took a different path than in Western European countries. Lithuania was largely an agrarian society until the Second World War (Norkus 2008), and the majority of the population lived in rural areas. Historians argue that in the eighteenth and nineteenth centuries, only $5 \%$ of men and women remained unmarried in Baltic countries. Agrarian culture forced young men and women to marry so that the family estate could be divided properly among brothers and sisters. Those who remained single could not gain any property and had to serve other family members (Marcinkevičienè 1999). The rural area culture was grounded in Roman Catholic Church values, which considered childlessness among married couples as punishment from God. Women felt the burden of guilt, used folk medicine and prayed for fertility (Račiūnaitè 2004). Avoiding motherhood or giving birth outside marriage was against Catholic values. Some mothers used rituals to prevent their daughters from giving birth outside marriage (Lebednykaite 2015). Couples did not use contraception, and rural families used to have between 7 and 12 children, sometimes even more (Račiūnaite 2004). It was only after World War II that abortions became legal and came into practice (Sobotka 2003). Only a small portion of women from urban bourgeois families were housewives with husbands as sole breadwinners (Maslauskaite 2008); the majority of women participated in the labour force. A structural female emancipation was achieved in some spheres during the Soviet period, such as women's activity in labour and achieving higher education, without achieving equality in gender relations in the private sphere (Stakuniene and Maslauskaite 2008).

During the Soviet period, after rapid industrialization, women's work in the public sector became their core identity. However, the traditional division of housework and childcare remained unchanged, and women carried the main responsibility. Balancing childcare and work responsibilities was achieved by including relatives from the extended family, such as grandmothers and aunts. Older children from the same family were also included into childcare tasks. Children of preschool age used to live a big part of their childhoods at their grandparents' or at other relatives', or they would spend a lot of time in the yards with a key around the neck (Marcinkevičienè 2008) and had to be independent when they were left at home alone. Preschool childcare institutions did not cover the demand, and fathers remained less involved in raising children. The ideal of a woman during the Soviet period was 'wifeemployee-mother' (Marcinkevičienè and Praspaliauskienè 1999, 63), as married women with children had higher status in society in comparison with single and childless women.

After the 1990s, the new political democracy and market economy in Eastern European countries did not encourage female emancipation. On the contrary, patriarchal models of public and private domain divisions were strengthened. Female identity was associated with the private sphere and family life, and men's identity, with the public sphere. Single women remained marginalized (Marcinkevičienè and 
Praspaliauskienè 1999). The quantitative survey taken after a decade (IPPAS 2000-2003) showed that Eastern European countries differed in female identity models (Stakuniene and Maslauskaite 2008). No single female identity model was found in Lithuania. Respondents did not agree on a position: the same proportion of the population supported emancipation, limited emancipation and limited patriarchy models. Vlada Stankuniene and Ausra Maslauskaite (2008) concluded that negative attitudes towards family changes with family transformations in practice, as well as changes in family formation, are accepted more often than the decline in fertility.

Thus, the historical context of Lithuania exemplifies how involvement in childcare tasks spill over into the nuclear family networks: grandparents or other relatives are included in raising children. In this chapter, we use the concept of 'community parenting' (Kessler 2007:49; Evans and Holland 2012) as the most accurate description of this involvement, which expands the traditional definition of parenthood.

\section{Method}

The data about the role of children in childless women's lives were gathered in the framework of the project 'Childlessness in Lithuania: Socio-cultural Changes and Individual Experiences in Modern Society', financed by the Lithuanian Science Foundation, No. S-MOD-17-3. Results incorporated in this chapter received funding from the European Union's Horizon 2020 research and innovation programme under grant agreement No 952366. The analysis is based on 40 semi-structured qualitative interviews, conducted in 2017-2018, with single and coupled women who are voluntarily and involuntarily childless. Two generations of women were interviewed: those who are still in their reproductive years and those who are beyond their reproductive years.

At the time of the interview, the women in the first group were between 27 and 49 years of age. In the chapter, they are referred to as the younger women. They represented the option of postponing pregnancy or remaining childless due to physiological or circumstantial reasons, or because they decided to be childfree. We chose 27 as the youngest age for the research participant because it was approximately the average age of a first delivery (27.5 years) in Lithuania in 2017 (Demografijos 2018). The upper age of the younger group, 49 years, was chosen in relation to the final reproductive years. Even if the possibility of getting pregnant after 45 years is low and is rarely used in quantitative studies of childlessness rate in society (Sobotka 2017), women are officially considered of reproductive age up to 49 years (WHO 2020). Our oldest interviewee in the first group was 47 years old. In the second group, at the time of the interview, the women were between 50 and 71 years old. This group of women remained childless due to life's circumstances or for physiological reasons. Several of them also revealed childfree attitudes, though 
seldom explicitly. We refer to this group as the older women in the article. (Demographic characteristics for both age groups of women can be found in the Appendix).

The interview guide included questions on reasons, circumstances and experiences of childlessness/being childfree. The questions on the women's relationships with other people's children were not the main focus of the interviews. However, we gathered rich data on the ways the relationships work between women with no children and other people's children.

Interviewees were found using the snowball method in the network of acquaintances of the researchers and selected according to the criteria of heterogeneity. The interviews were conducted in different areas of Lithuania, including large cities, small towns and rural areas, with women of different social backgrounds (in terms of socioeconomic status and level of education, and they represented various partnership types: single, married, or cohabiting). The sample included more women with college or university educations. In Lithuania, the share of childless/childfree women with higher education is higher compared to women with higher education who have children (Gedvilaitè-Kordušienè et al. 2019). Thus, it was quite difficult to find interview participants without college educations, especially in the group of younger women.

Using both deductive and inductive methods of social inquiry, the interview material was coded using the Maxqda programme (version 18). The coding and categorizing process was based on each researcher finding common topics and comparing, discussing and creating topics afterwards. The themes that resulted from the analyses are presented in the following sections.

\section{Communication with Children of Others}

Reasons and thoughts about being childfree varied greatly among the women in our sample. The narratives ranged from a neutral position to mixed feelings or feelings of sorrow, while some women saw the advantages of being childless. Some narratives from the older generation illustrated a lack of agency, stressing fate or God's will when explaining the reasons for permanent childlessness. Meanwhile, more individualistic attitudes prevailed in the narratives of women of reproductive age. Among these women, cases of voluntary childlessness were clearly expressed, while in the narratives of post-reproductive-aged women, childfreeness was only implicit. The narratives of women who had chosen to be childfree were less overtly emotional compared to involuntary and circumstantial cases.

While reasons for childlessness differed within and between the two generations of women, interview data illustrate that women from both groups were involved in various forms of interactions with children. This was frequently considered as a natural part of social life.

Most often the described relationships with children were based on blood ties, such as siblings' children. However, there were cases when close relationships were 
established through the partner's family (e.g. children from previous partnerships) or outside kin ties with children of friends or neighbours. Most of the women from the older generation had provided childcare in their youth, and several of them still did so. Along with intensive parenting work, support was provided through other important tasks: walking siblings' children to leisure activities such as cultural activities (going to theatre -- Stasè 61) and sports activities (canoeing and skiing Brone 56; cycling, going to the swimming pool - Neringa 35); taking children home overnight (women from younger generation - Gryte 29, Monika 31), and spending time together with children during weekends and holidays (Jorè 29, Virga 47, Adelè 63, Nijole 61). Women of both generations also stated that these various activities give them joy (Stase 61, Nijolè 61, Adelè 63, Virga 47). Virga, 47, said that spending time with children is 'more fun' than travelling alone.

For some women in the older generation, childcare in their youth was perceived as a duty. They recalled that there was not much choice - they had to help: '... nobody asked me, I was 11 years old, and my cousin was young. I remember very clearly, my mother said very strictly, we must help [to raise a daughter of the cousin] [...] so I had to play with the kid...' (Aniceta 57).

We identified three groups of women based on relationships with children of others: (1) those who considered the children of others as their own, (2) those who had friendships with children of others, and (3) those who had distant relationships with children.

\section{Children of Others As Their Own}

The women who saw other people's children as their own included Adelè (63), Liucija (62), Teklè (61), Nijolè (61), Stasè (61), Bronè (56), Rasa (50), Virga (47), Danguolè (44) and Inga (35). In most cases, they used to or still were providing occasional or long-term childcare, and this leads to closeness. Parenting work was the way relationships were defined: to love somebody equals taking care of them. These cases represent one way of making sense of relationships, where the central role is rendered to caring practices. Some women from the older generation emphasized the reciprocity of relationships: they were loved by children and children always wanted to be in contact with them (Brone 56, Stasè 61). The reciprocity was also expressed by some older women when they spoke about their expectations of receiving care at an older age from the children they have close relationships with.

Since children were considered their own in the framework of the extended family, involvement in childcare was perceived as 'natural' and taken for granted. Nijole $(61)^{1}$ remembered her important role while helping her single sister in childrearing

\footnotetext{
${ }^{1}$ Nijole was married, but her husband had an accident at work and she had to care for him, 'like [looking] after a child' for a period of one year. During this period, she 'lost interest in him as a man.' Even though the couple stayed together, the question of having children of their own had not been raised in the relationship.
} 
tasks: 'I am not saying I raised the children, but I helped a lot, and it feels like they are mine.' She further discussed the ways in which she helped, such as taking children on holidays, allowing their mother to go on business trips, all of which suggest community parenting. She talked about the reciprocity of her relationship with the children: 'They used to spend time at my place, they had a lot of freedom, and thus, I have two children that I love and they love me back' (Nijolè 61).

Similarly, Bronè (56) recalled the help she provided for her niece and goddaughter, like they were her own children. She never refused to help her friends with childcare as well ('...because they knew that I would never refuse, that I love [the children]'). Brone did not know the reason why she and her husband had not been able to have children, as they had both been 'quite healthy'. Fertility treatment services were undeveloped in the late Soviet period (Brone got married in 1986), and later on looking after her old mother and her own husband became her duty: "maybe my mission is to take care of those less fortunate people than to be joyful about children' (Bronè 56).

A few of the other women from the older group expressed the same attitudes towards children of relatives, but they differed in the sense that they illustrated shared childrearing arrangements in Lithuania during the Soviet period (Marcinkevičienė 2008) when children used to move into different households for periods of time. Rasa (50) remained childless after experiencing a few miscarriages. Her case represents a childcare arrangement related not only to a transnational family form but also to the dearth in formal childcare options in a rural area. Rasa's brother-in-law had a job abroad, and his wife also had to work, so for one summer Rasa was a substitute mother for her nephew, who at that time was under three:

So, I used to do everything: laundry, provide food, we slept in the same bed, I raised him as my own. At that time, I had a landline, so he used to call his mum and talk in his language (laughs). So, we used to take him with us everywhere, we spoiled him, and bought him what he wanted. (Rasa, 50)

The same community parenting arrangement was described by Stasè (61), who was not able to have biological children because of medical reasons; doctors recommended avoiding pregnancy. Nevertheless, she experienced social motherhood while taking care of her husband's son from a previous marriage, and she also took in her nephew to live with them. For this woman, a reconstituted family and networks outside the family were compensational mechanisms for not having biological children:

In the beginning, I grieved this loss [from miscarriage], but there was a child from my husband's first marriage, then his children, then grandchildren, and we had enough to take care of. So, that was compensation, because I was torturing myself at first [for not having a biological child]. Later, I helped my good friend raise her daughters, so that compensated for everything. (Stasé, 61).

The decision to offer to move her nephew from another city was made as a way to help her brother financially. The boy lived at Stase's home from grade 4 to the last year of secondary school. Now she considers him to be her own son and identifies him and his children as her closest family members. 
The topic of common children came up in the younger women's group as well. Danguole (44), who was not able to conceive, as she married late ${ }^{2}$ and had fertility issues, was faced with feelings of loss from close family members. However, after her sister gave birth to two girls, the situation changed. Her statement describing the family situation points towards experiences of collectivity and away from individualism:

It seems to me, we all have the two [daughters], so they are a substitute fulfilment for all of
us. My sister conceived late, so before that, you could feel an unpleasant emptiness... [...] It
was somehow cold, like a deep hole, but when the first one was born, so much happiness...
And when the second was born, we had everything (laughs). It seems everything is common
for us: common home, children (laughs). Common feelings. (Danguole, 44)

Though Danguole expresses ideas that suggest community parenting, she reported that she meets up with her sisters' children too seldom for them to fulfil her desire for a close relationship with a child.

Virga (47), who is single, also reported sharing childcare responsibilities with the whole family. As she grew up in the countryside in a big family of 5 children (she was the oldest), sharing all the domestic tasks and later on looking after a sibling's children was perceived as natural:

When my brother's children were small, my brother studied, his wife studied [at universities] [...] Children often stayed at the grandparents'. I was working in my native town at that time. Then we all together... [looked after children]. [...] Whoever needed help, we used to watch them. (Virga, 47)

Virga's relationships with children or kin illustrate a system of community parenting served as a compensational mechanism for not having her own. She reported that relationships with nieces and nephews let her actualize 'some part of womanhood', as she says; however, she does not feel any dilemma about having a child of her own because she has not met a proper partner. She likes doing handicrafts and recently began to sew clothes for her niece's dolls:

...only to have a child, I haven't felt like that. To actualize womanhood, I have my ways... without children. [...] I have nephews, nieces. I always wanted to sew something for my sister's dolls. While I was studying, I had no time, and now, recently [...] [I sew] clothes for Barbies [...] for my niece, my goddaughter... (Virga, 47)

Inga $(35)^{3}$ reports having close relationships with the children of a friend. She helped her with childcare for a period of time, when the husband of the friend worked abroad. Since then she has had very close relationships with these children, one where she participates in aspects of parenting:

We are like a family [...] We have very close relationships and we often meet up with children. When they were born, I was at their place very often. Since her husband had a job in

\footnotetext{
${ }^{2}$ It is a second marriage for Danguole's husband. He has a daughter from a first marriage, so he has not expressed any sorrow for not having children with Danguolè.

${ }^{3}$ Inga was going through infertility treatment with her husband and expected to have positive results. They had agreed to adopt a child if the procedure was not successful.
} 
Norway, it was very hard for her. I had no job and no studies at that time, so I spent a lot of time in her place and helped to raise those children (Inga, 35)

However, Inga describes her relationship with her nephew as cold, as they meet seldom and her relationship with her brother is conflict-laden. Inga's case reveals how relationships with friends' children can be closer than those within the kinship network. On the one hand, closeness with children depends on the relationships with the children's parents. On the other hand, Inga represents women of a younger generation who express less obligation and more freedom when choosing to help with childcare.

To summarize, most of the cases discussed above illustrate how children gained the central role in familial networks. However, as mentioned in Stasè's (61), Teklè's (61) and Inga's (35) cases, close relationships with children were also established outside kinship networks. This tendency of a blurred boundary between relatives and friends in modern society is discussed by Ray Pahl and Liz Spencer (2004, 200-203), who question the division between family as 'given' and friends as 'chosen' and suggest the idea of the complex process of suffusion between familial and non-familial relationships. In our study, extended kin and non-kin relationships were included in the closest circles. The interviewees' statements, which demonstrate how close relationships were constructed through mothering practices, signify the ways that the family is being reconceptualized. The notion of family is expanding from a narrow definition based on blood and genes to a broader one. The broader definition captures the commitment of chosen, rather than fixed relationships, like in 'families of choice' (McCarthy and Edwards 2011). If there was a feeling of obligation when making the decision to take care of kin in the interviews with the older women, this was absent when women considered non-kin relationships as familial.

\section{Friendship with Children of Others}

The second group of women identified close relationships with children of others, but did not consider them as their own: Stefa (71), Elena (60), Veronika (62), Antanina (59), Petrutè (58), Marytè (56), Marija (55), Dalia (55), Rugilè, (44), Magdalena (39), Norvilè (36), Neringa (35), Goda (31), Monika (31), Milda (31), Jorè (29), Grytė (29) and Eglè (29). Still, this group of women participated actively in support networks for the children, had frequent contact and described the role of children in their lives in terms of friendship.

Many cases of intensive involvement in support networks can be found in the group of younger women. The support is provided within familial networks in certain periods in these children's lives when such care is needed the most. For example, Goda (31), who has a partner and plans to have children later, recalled how she used to look after a nephew. Her sister and her baby lived with their parents until her 
apartment was ready. Goda was a student at that time and used to look after a child at nights along with her mother, in an example of community parenting.

\begin{abstract}
When a child is crying the whole night and you don't know, why...[...] We used to alternate, my mother used to rock him, then me, until he grew to be 7-9 months [...] I rocked him at night, then [...] my sister's husband drove me to lectures [in another city] and I fell asleep during seminars [...] We are now very good friends [with the nephew] [...] I can come down to the child's level [...] We come up with all sorts of things [...] Sometimes grandma used to scold us. (Goda, 31)
\end{abstract}

Friendships or friendly relationships with the children of sisters were discussed by Monika (31), who lives in a non-traditional family with her female partner. She would like to have children, though her partner does not agree with the idea because of the amount of responsibility and negative attitudes towards the LGBTQ community in Lithuania. The couple often meets up with Monika's sister's family and takes cares of her children when they are sick, suggesting elements of community parenting. Children also stay at their place for a night or the whole weekend when their parents want to have some time for themselves.

Our relationship [with children] is wonderful, we love them very much and they love us very much $[\ldots]$ We meet up every week, sometimes every day, it depends $[\ldots]$ In the future, when they grow up we would like to take them for holidays [...] We like to spend time with children and not commit to full-time [...] Especially my partner [...] She always says, look how cool it is, they will go home and we will have a free evening. If they were ours, our children, it wouldn't be like that. (Monika, 31).

Neringa (35) also has a close relationship with her brother's children; she likes to spend her free time with them and wants to have children of her own. She would consider trying artificial insemination if she does not find a proper partner in the near future. Contrary to the opinion usually expressed by other single women in the research that a child has to have a father, Neringa thinks that connections with a grandfather and an uncle would be appropriate male role models in the family for children.

Jore (29), who was trying to get pregnant, revealed ambivalent feelings: she liked when her husband's or friends' children visited, but at the same time, she noticed she got tired or irritated. Egle (29), who was trying to conceive with her husband and was going through fertility treatments, became friends with one boy when she was employed at a children's foster home before marriage. She used to take him home during weekends and became his godmother, as his grandmother wished. Now their relationship had become more distant since she had moved from the city where he lives. Grytė (29), who plans on having children after marrying her partner next year, had a friendly relationship with her sister's small children, but her relationship is more distant with the children of her partner's sister, explaining that she has spent more time with her sister's children. However, she thinks her partner has a closer connection with children ('he knows how to accommodate them'). 
In the group of older women, some cases demonstrate how love for children was included in the core of their identity. For example, Marija ${ }^{4}$ (55) shared that she had been known as the one who loved children; she used to spend a lot of time with them. However, she began drawing boundaries: 'I gave them so much and eventually got tired, so now I try to limit my contact. [...] Afterward, I have to regain my strength' (Marija, 55).

When motherhood in a pronatalist society is a central aspect of femininity, the education sector, which is still very feminized in Lithuania, is a favourable area where internalized norms can be realized. Some of the interviewed women identified their interaction with children in the education sector as a compensational mechanism for not having their own children. The women worked at schools and kindergartens, gave private piano lessons and met up with children in their leisure time activities, such as choir, or camps. Elena ${ }^{5}(60)$, who worked at a kindergarten, listed care practices that went beyond work responsibilities, such as washing clothes of children from at-risk families or helping with hygiene. Personal importance was given to these activities. She went on to describe her work with the girls' choir and the kindergarten in the framework of the intergenerational continuity of interaction that gives meaning to her life:

We used to take around 70 girls to Giruliai [a camp by the seaside]. We socialized like this... So, even today, we meet up with each other and get along well. They come to visit me and bring their children. The girls bring their daughters to choir, and the girls from the kindergarten bring their children. So, I feel like I achieved something in life. (Elena, 60).

Dalia (55), Antanina (59) and Elena (60) are single, as they had not met the right partner for having children. This group of women emphasized not longing for a child since they have regular opportunities to take care of children at work: 'Especially if you work in education, you are always surrounded by children.' (Antanina, 59); 'I witness childhood from morning till evening.' (Dalia, 55).

The longing for children is most clearly expressed by divorced Raimonda (51), whose husband had fertility issues. She has several godchildren and used to like spending time with them. Now that they are grown up, she does not see them very often, and some parts of her narrative reflect longing for children:

...it's sad during festivals, it's sad to live without children [...] but you accept that and I try not to delve deeper into it, if you begin, will be even harder. [...] We talk among friends, cousins $[\ldots]$ not having children is not a cancer [...] It is not a tragedy, not a problem, just such life is a bit different. [...] It's good that my relatives don't push me away, invited me to baptize children [...]. I sort-of compensate sometimes this way, given that I don't have my own children.

Raimonda's example shows an internalization of the stigma of not having children. While analysing childless women in Israel, Daphna Yeshua-Katz (2018) found that

\footnotetext{
${ }^{4}$ Has remained childless because of not finding a partner.

${ }^{5}$ Her narrative reveals circumstantial reasons of childlessness: loss of her first boyfriend in an accident and not finding another partner since then.
} 
childlessness often is experienced as a stigma in pronatalist society, and one of the coping mechanisms can be the internalization of the stigma.

If work with children as a compensational mechanism was more clearly expressed by some older women, it was also considered by a few women from the younger generation. Norvilè (36) was not able to conceive due to unknown reasons ${ }^{6}$ but is the godmother of a few of her friends' children. She emphasized her love for children and her willingness to play with them. Thus, she admitted sometimes considering working as a nanny - this could function as a partial compensation for not having children of her own and be a positive experience:

When I am with a child, I feel happy, I have noticed that. For example, there are parties where I consciously choose to leave the table. The topics and discussions sometimes are not interesting to me, and I play joyfully with children of all ages. (Norvilè, 36)

In the group of women with friendly relationships with children at work, some had made decisions to stay childfree and refuted the myth that childfree people are selfish and do not like children under any circumstances (Gillespie 1999):

I often have contact [with children] and they like me. [...] I even teach people how to work with children. [...] I like children, that they are natural, I like everything [...] where you can have a direct contact $[\ldots]$. It is quite easy to have it with children, even with teenagers $[\ldots]$ you just discover it, because you don't hide yourself... (Rugilè, 44)

Studying the interview material, we noted that the group of women who built friendly relationships with children of others was the largest in our research. Some of them, working in the educational sector, had a professional relationship with children that went beyond work obligations. Pahl and Spencer (2004) claim that the category of 'friend' conveys a relationship with sympathy and fun. When people in a familial relationship 'enjoy each other's company in a friend-like way' (Pahl and Spencer 2004, 213), and, conversely, professional relationships demonstrate familial commitment, the authors argue that the boundaries between family and friendship are blurred. Personal communities can also go beyond the traditional division of family and friendship.

\section{Distant (Indifferent) Relationships with Children of Others}

The last group of women identified their relationship with children of relatives or friends as rather distant. They feel indifferent, and/or do not have frequent contacts with them: Agota (56), Jūratè (54), Kotryna (51), Onutè (51), Dagnè (45), Toma (39), Kristina (39), Sigita (35), Paulina (32), and Simona (28).

\footnotetext{
${ }^{6}$ Norvilè's husband believes that he has been infertile since childhood because of illness. His infertility has never been properly valuated since he refuses to do so. Gynecologists had not found any fertility issues with Norvile. They had been married for 6 years, and Norvile tried to conceive right before getting married.
} 
Dagnè, who belongs to the younger generation, made a distinction between relationships with children of others and children of her sibling. With her sibling's grown children she still has a bond, even if they communicate rarely, now that they are grown up. Kristina (39) also stated that she loves her nieces but said she had an indifferent attitude towards the children of others. Paulina (32), who states an active childfree position, drew a parallel between adults and children, stating that children could be good or bad, just like adults, and admitted that she liked some children but not others (the spoiled ones).

Three women from the older generation who had distant relationships with children of others had childfree attitudes, even though they did not describe their choices as voluntary. For example, Onute (51) says, 'When sometimes people say that it is a tragedy to get uterus surgery [for medical reasons]... "It won't be possible to have children," I answer: “oh God, what a problem, it's not a big deal” (laugh).' Onutè's contact with children happens rarely, only once or twice a year, and she identified the challenges of more frequent contact: she got tired, did not know how to deal with them, and they were too energetic for her age. Kotryna (51) said she had no time to look after other people's children, as she spends most of her time at work. As an only child, she and her parents had a small family network and had no obligations to look after relatives' children. Agota (56) revealed that though she took care of friends' and her brother's small children in the past, it was a negative experience to take care of her friend's children when her boundaries were violated: 'Especially friends [...] they used to bring their children to my home, sometimes without warning and told me that their children should be more important than my plans at the moment' (Agota 56).

For Jūratė (54), contact with children sometimes elicited painful feelings. She lost her child just after birth and avoided children after this traumatic event.

A few women from the younger generation (Dagnè 45, Toma 39, Kristina 39) stated that they were pushed away after their friends had children, so they chose to have contact mostly with childless people:

It is even difficult to schedule time with friends who have little children because they have to adjust to their schedule. Thus, we mostly have contact with those who have adult children or do not have children at all. [...] There are a few families with children that we have contact with. So, if we travel together, afterwards we say: 'No, no, it was a catastrophe to travel with children (laughs)'. Parents understand this perfectly as well... (Kristina, 39).

The consequences of childfree lives, including the narrowed circle of friends, can be viewed in terms of Yeshua-Katz's (2018) four types of reactions to the stigma of childlessness: stigma internalization, stigma challenging, stigma avoidance and group identification. Women who avoided contacts with children could be identified as challenging the childlessness stigma and were seeking group identification with other childfree people. They identified the childfree status as an acceptable lifestyle for themselves, and at the same time, they spent most of the time with other childfree people.

These women from the younger generation also took a critical position towards pronatalism and voiced other views on femininity and motherhood. Paulina (32) 
criticized a basic assumption in pronatalist societies: 'I have heard that if a woman does not want to have children, she is not a woman, she has no right to exist because her existence is based on giving birth.' The pressure she received in her social environment encouraged her to avoid any discussions on childlessness. Childless women in pronatalist societies often hear stigmatizing remarks (Letherby 1999, 2002). Based on the examples of her close friends, Kristina (39) took a critical position towards contemporary motherhood and parenthood because of a few challenges: combining private and public spheres and setting boundaries for young children. Having a husband with disability and after unsuccessful attempts to conceive during their first years of marriage, later on she made a conscious choice to stay childfree. This decision was based not only on her husband's disability but also on the issues that contemporary motherhood would bring.

More generally, looking at all types of relationships between childless women and children of siblings (in most cases), other relatives, children from a partner's previous partnership and friends, interview data reveal the important role of childless women in community parenting practices. Women who identified children of other people as their own were mostly from the older generation. Time resources were necessary to create such relationships. Other types of relationships with children of other people (those based on friendship and distant relationships) were revealed among women from both age groups. The women with childfree attitudes towards children mostly built friendly or indifferent relationship with children; they were satisfied with their lifestyle and challenged the pronatalist family pattern of getting married and raising children.

\section{Conclusions}

Helping to raise children of relatives was a common practice in rural Lithuania in the beginning of twentieth century. Such practices remained during the Soviet period because of lack of public childcare services (Marcinkevičienè 2008). Thus, there is evidence of path dependency in non-biological parents' involvement into parenting tasks. The concept of community parenting, which we use in this article, expands the traditional definition of parenthood and questions the nuclear family as an isolated unit. Furthermore, it reflects the essence of pronatalist society, illustrating how women with no children are nevertheless included into childcare networks.

Based on our qualitative analysis, the women from the first group, who established very close relationships with children of kin or in friends' networks and perceived children as their own, usually spent some period of time living together with children or visited them so often, they could say they provided help in raising the children. The older generation of women perceived this help with raising children of others as natural and unquestionable, as they saw such examples from childhood in their own family networks. Some of them also had experience in taking care of adults who need care. Younger women in this group build close relationships with children of others by helping to raise them as well and were involved in community 
parenting practices, though the younger women did not emphasize the duty in providing childcare. However, those who had fertility issues reported that these children only served as partial substitutes for biological children. In the cases where a partner had children from previous union, the women did not see themselves in the role of a stepmother, as those children lived with their biological mothers.

Friendly relationships with children are built not only by taking care of siblings' or friends' children or spending time with them but also by having professional relationships with children at schools, kindergartens, children choirs, foster homes, camp, and other settings. Closer relationships were built with smaller children, as they need more attention, and women reported getting along better with them in comparison with teenagers. The narratives of the younger generation reveal an element of choice in their contact with children; some of them emphasized that relationships with children brought joy and that it was something fun to do.

The role of other people's children was less significant for the third group, where women defined their relationships with children as distant. Here we could argue that group identification with other childless people (Yeshua-Katz 2018) shows more individualistic values in society, which are present because of decreasing pronatalist values in contemporary Lithuanian society (Gedvilaitė-Kordušienè et al. 2019).

Critical positions towards the pronatalist ideology were not just common among the women in the younger generation. Some of the older women, especially those with a higher education background, also questioned the normative construct of women's necessity to procreate. However, only in the younger group were these critical views considered when making personal decisions. It might be that pronatalist values, which were strong in the Interwar and Soviet periods in Lithuania, (Marcinkevičienè 1999, 2008) are loosening and providing space for more individualistic ones.

The findings revealed the ways kin and non-kin members are included in parenting tasks. This suggests a reconsidering of the notion of the nuclear family as an isolated unit, as childless or childfree women are involved in childcare tasks either occasionally or for longer periods of time. Such support is very important in Lithuania, where families in the largest cities and in the countryside are still facing shortages of preschool childcare services. The feminization of care work predetermines that such childcare support is not considered as important by childless women. They perceive it as 'natural', taken for granted, especially among women in the older generation. However, our study demonstrates a significant social investment of childless women in familial and non-familial networks. Results also suggest that traditional kinship patterns still play their role in contemporary families. Even if the motives for participation in care networks by women in the younger generation are different and signify more individualistic attitudes, they continue to be involved in childcare activities.

Acknowledgements This chapter has received funding from the European Union's Horizon 2020 research and innovation programme under grant agreement No 952366. 


\section{Appendix (Tables 1 and 2)}

Table 1 Demographic characteristics of the younger generation of childless women

\begin{tabular}{|c|c|c|c|c|c|c|c|}
\hline No. & Name & $\begin{array}{l}\text { Younger } \\
\text { age group } \\
(28-47)\end{array}$ & Education & $\begin{array}{l}\text { Living } \\
\text { place }\end{array}$ & $\begin{array}{l}\text { Marital } \\
\text { status }\end{array}$ & $\begin{array}{l}\text { Living } \\
\text { with }\end{array}$ & $\begin{array}{l}\text { Type of } \\
\text { childlessness }\end{array}$ \\
\hline 1 & Dagnè & 45 & Master's & $\begin{array}{l}\text { Big } \\
\text { city }\end{array}$ & Single & Alone & $\begin{array}{l}\text { Circumstantial/ } \\
\text { late partnership }\end{array}$ \\
\hline 2 & Rugilè & 44 & Master's & $\begin{array}{l}\text { Big } \\
\text { city }\end{array}$ & Divorced & $\begin{array}{l}\text { With male } \\
\text { partner }\end{array}$ & Voluntary \\
\hline 3 & Toma & 39 & Master's & $\begin{array}{l}\text { Big } \\
\text { city }\end{array}$ & Single & Alone & $\begin{array}{l}\text { Circumstantial/no } \\
\text { partner }\end{array}$ \\
\hline 4 & Goda & 31 & Master's & $\begin{array}{l}\text { Small } \\
\text { city }\end{array}$ & $\begin{array}{l}\text { Single/ } \\
\text { Engaged }\end{array}$ & $\begin{array}{l}\text { With } \\
\text { parents }\end{array}$ & Postponement \\
\hline 5 & Jorè & 29 & Bachelor's & Village & Married & $\begin{array}{l}\text { With } \\
\text { husband }\end{array}$ & $\begin{array}{l}\text { Physiological } \\
\text { (getting some } \\
\text { fertility } \\
\text { treatment) }\end{array}$ \\
\hline 6 & Norvilè & 36 & Bachelor's & $\begin{array}{l}\text { Big } \\
\text { city }\end{array}$ & Married & $\begin{array}{l}\text { With } \\
\text { husband }\end{array}$ & $\begin{array}{l}\text { Physiological } \\
\text { (not-diagnosed) }\end{array}$ \\
\hline 7 & Sigita & 35 & $\begin{array}{l}\text { Bachelor's } \\
\text { (College) }\end{array}$ & $\begin{array}{l}\text { Big } \\
\text { city }\end{array}$ & Single & $\begin{array}{l}\text { With } \\
\text { roommate }\end{array}$ & $\begin{array}{l}\text { Circumstantial/no } \\
\text { partner }\end{array}$ \\
\hline 8 & Virga & 47 & $\begin{array}{l}\text { Higher } \\
\text { education } \\
\text { (not divided } \\
\text { into } \\
\text { Bachelor's } \\
\text { and Master's) }\end{array}$ & $\begin{array}{l}\text { Big } \\
\text { city }\end{array}$ & Single & Alone & $\begin{array}{l}\text { Circumstantial/no } \\
\text { partner }\end{array}$ \\
\hline 9 & Neringa & 35 & Master's & $\begin{array}{l}\text { Big } \\
\text { city }\end{array}$ & Single & Alone & $\begin{array}{l}\text { Circumstantial/no } \\
\text { partner }\end{array}$ \\
\hline 10 & Eglè & 29 & Bachelor's & $\begin{array}{l}\text { Small } \\
\text { city }\end{array}$ & Married & $\begin{array}{l}\text { With } \\
\text { husband }\end{array}$ & $\begin{array}{l}\text { Physiological } \\
\text { (going through } \\
\text { infertility } \\
\text { treatment) }\end{array}$ \\
\hline 11 & Inga & 35 & $\begin{array}{l}\text { Bachelor's } \\
\text { (College) }\end{array}$ & $\begin{array}{l}\text { Big } \\
\text { city }\end{array}$ & Married & $\begin{array}{l}\text { With } \\
\text { husband }\end{array}$ & $\begin{array}{l}\text { Physiological } \\
\text { (going through } \\
\text { infertility } \\
\text { treatment) }\end{array}$ \\
\hline 12 & Monika & 31 & Bachelor's & $\begin{array}{l}\text { Big } \\
\text { city }\end{array}$ & Single & $\begin{array}{l}\text { With } \\
\text { female } \\
\text { partner }\end{array}$ & $\begin{array}{l}\text { Circumstantial/ } \\
\text { partner rejection }\end{array}$ \\
\hline 13 & Grytė & 29 & Master's & $\begin{array}{l}\text { Big } \\
\text { city }\end{array}$ & Single & $\begin{array}{l}\text { With male } \\
\text { partner }\end{array}$ & Postponement \\
\hline 14 & Kristina & 39 & $\mathrm{PhD}$ & $\begin{array}{l}\text { Small } \\
\text { city }\end{array}$ & Married & $\begin{array}{l}\text { With } \\
\text { husband }\end{array}$ & $\begin{array}{l}\text { Physiological } \\
\text { (not diagnosed) }\end{array}$ \\
\hline 15 & Magdalena & 39 & Master's & $\begin{array}{l}\text { Small } \\
\text { city }\end{array}$ & Married & $\begin{array}{l}\text { With } \\
\text { husband }\end{array}$ & $\begin{array}{l}\text { Physiological } \\
\text { (not diagnosed) }\end{array}$ \\
\hline 16 & Danguolè & 44 & Master's & $\begin{array}{l}\text { Small } \\
\text { city }\end{array}$ & Married & $\begin{array}{l}\text { With } \\
\text { husband }\end{array}$ & $\begin{array}{l}\text { Circumstantial/ } \\
\text { late partnership }\end{array}$ \\
\hline
\end{tabular}


Table 1 (continued)

\begin{tabular}{l|l|l|l|l|l|l|l}
\hline No. & Name & $\begin{array}{l}\text { Younger } \\
\text { age group } \\
(28-47)\end{array}$ & Education & $\begin{array}{l}\text { Living } \\
\text { place }\end{array}$ & $\begin{array}{l}\text { Marital } \\
\text { status }\end{array}$ & $\begin{array}{l}\text { Living } \\
\text { with }\end{array}$ & $\begin{array}{l}\text { Type of } \\
\text { childlessness }\end{array}$ \\
\hline 17 & Paulina & 32 & $\begin{array}{l}\text { Secondary } \\
\text { (did not finish } \\
\text { higher } \\
\text { education })\end{array}$ & $\begin{array}{l}\text { Big } \\
\text { city }\end{array}$ & Single & Alone & Voluntary \\
\hline 18 & Simona & 28 & $\begin{array}{l}\text { PhD } \\
\text { candidate }\end{array}$ & $\begin{array}{l}\text { Big } \\
\text { city }\end{array}$ & Engaged & $\begin{array}{l}\text { With } \\
\text { husband }\end{array}$ & Voluntary \\
\hline 19 & Milda & 31 & Master's & $\begin{array}{l}\text { Big } \\
\text { city }\end{array}$ & Single & Alone & $\begin{array}{l}\text { Circumstantial/no } \\
\text { partner }\end{array}$ \\
\hline
\end{tabular}

Table 2 Demographic characteristics of the older generation of childless women

\begin{tabular}{|c|c|c|c|c|c|c|c|}
\hline No. & Name & $\begin{array}{l}\text { Older } \\
\text { age } \\
\text { group } \\
(50- \\
71)\end{array}$ & Education $^{\mathrm{a}}$ & $\begin{array}{l}\text { Living } \\
\text { place }\end{array}$ & $\begin{array}{l}\text { Marital } \\
\text { status }\end{array}$ & $\begin{array}{l}\text { Living } \\
\text { with }\end{array}$ & Type of childlessness \\
\hline 1 & Elena & 60 & Bachelor's & $\begin{array}{l}\text { Big } \\
\text { city }\end{array}$ & Single & $\begin{array}{l}\text { With } \\
\text { mother }\end{array}$ & $\begin{array}{l}\text { Circumstantial/no } \\
\text { partner }\end{array}$ \\
\hline 2 & Adelè & 63 & $\begin{array}{l}\text { Secondary } \\
\text { with } \\
\text { profession }\end{array}$ & $\begin{array}{l}\text { Big } \\
\text { city }\end{array}$ & Widowed & Alone & $\begin{array}{l}\text { Infertility of the } \\
\text { partner }\end{array}$ \\
\hline 3 & Petrutè & 58 & $\begin{array}{l}\text { Secondary } \\
\text { with } \\
\text { profession }\end{array}$ & Village & Married & $\begin{array}{l}\text { With } \\
\text { husband }\end{array}$ & $\begin{array}{l}\text { Infertility of the first } \\
\text { partner/went through } \\
\text { infertility treatment } \\
\text { process without } \\
\text { results }\end{array}$ \\
\hline 4 & Onutė & 51 & $\mathrm{PhD}$ & $\begin{array}{l}\text { Big } \\
\text { city }\end{array}$ & Single & $\begin{array}{l}\text { With } \\
\text { parents } \\
\text { and sister }\end{array}$ & $\begin{array}{l}\text { Mixed reasons: no } \\
\text { partner, physiological } \\
\text { issues }\end{array}$ \\
\hline 5 & Teklè & 61 & $\mathrm{PhD}$ & $\begin{array}{l}\text { Big } \\
\text { city }\end{array}$ & Single & Alone & $\begin{array}{l}\text { Circumstantial/no } \\
\text { partner }\end{array}$ \\
\hline 6 & Stefa & 71 & $\begin{array}{l}\text { Higher } \\
\text { education }^{\mathrm{a}}\end{array}$ & $\begin{array}{l}\text { Big } \\
\text { city }\end{array}$ & Single & Alone & $\begin{array}{l}\text { Circumstantial/no } \\
\text { partner }\end{array}$ \\
\hline 7 & Marytė & 56 & Master's & $\begin{array}{l}\text { Big } \\
\text { city }\end{array}$ & Married & $\begin{array}{l}\text { With } \\
\text { husband }\end{array}$ & $\begin{array}{l}\text { Mixed reasons: late } \\
\text { marriage, fertility } \\
\text { issues of the partner }\end{array}$ \\
\hline 8 & Antanina & 59 & $\begin{array}{l}\text { Higher } \\
\text { education }\end{array}$ & $\begin{array}{l}\text { Big } \\
\text { city }\end{array}$ & Single & Alone & $\begin{array}{l}\text { Circumstantial/no } \\
\text { partner }\end{array}$ \\
\hline 9 & Jūratė & 54 & $\begin{array}{l}\text { Secondary } \\
\text { with } \\
\text { profession }\end{array}$ & $\begin{array}{l}\text { Small } \\
\text { city }\end{array}$ & Divorced & Alone & $\begin{array}{l}\text { Loss of the baby after } \\
\text { birth }\end{array}$ \\
\hline 10 & Dalia & 55 & $\begin{array}{l}\text { Higher } \\
\text { education }\end{array}$ & $\begin{array}{l}\text { Small } \\
\text { city }\end{array}$ & Single & Alone & $\begin{array}{l}\text { Circumstantial/no } \\
\text { partner }\end{array}$ \\
\hline 11 & Nijolè & 61 & $\begin{array}{l}\text { Master (not } \\
\text { finished PhD) }\end{array}$ & $\begin{array}{l}\text { Small } \\
\text { city }\end{array}$ & Widowed & Alone & $\begin{array}{l}\text { Circumstantial/ } \\
\text { relationships issues }\end{array}$ \\
\hline 12 & Agota & 56 & $\begin{array}{l}\text { Higher } \\
\text { education }\end{array}$ & $\begin{array}{l}\text { Big } \\
\text { city }\end{array}$ & Single & $\begin{array}{l}\text { With } \\
\text { parents }\end{array}$ & $\begin{array}{l}\text { Circumstantial/no } \\
\text { partner }\end{array}$ \\
\hline
\end{tabular}


Table 2 (continued)

\begin{tabular}{|c|c|c|c|c|c|c|c|}
\hline No. & Name & $\begin{array}{l}\text { Older } \\
\text { age } \\
\text { group } \\
(50- \\
71)\end{array}$ & Education $^{\mathrm{a}}$ & $\begin{array}{l}\text { Living } \\
\text { place }\end{array}$ & $\begin{array}{l}\text { Marital } \\
\text { status }\end{array}$ & $\begin{array}{l}\text { Living } \\
\text { with }\end{array}$ & Type of childlessness \\
\hline 13 & Aniceta & 57 & $\begin{array}{l}\text { Higher } \\
\text { education }\end{array}$ & $\begin{array}{l}\text { Big } \\
\text { city }\end{array}$ & Single & Alone & $\begin{array}{l}\text { Mixed reasons: no } \\
\text { partner, physiological } \\
\text { issues }\end{array}$ \\
\hline 14 & Raimonda & 51 & Secondary & $\begin{array}{l}\text { Big } \\
\text { city }\end{array}$ & Divorced & $\begin{array}{l}\text { With } \\
\text { mother }\end{array}$ & $\begin{array}{l}\text { Mixed reasons: } \\
\text { infertility of husband, } \\
\text { late marriage }\end{array}$ \\
\hline 15 & Stasè & 61 & $\begin{array}{l}\text { Higher } \\
\text { education }\end{array}$ & $\begin{array}{l}\text { Big } \\
\text { city }\end{array}$ & Married & $\begin{array}{l}\text { With } \\
\text { husband }\end{array}$ & Physiological issues \\
\hline 16 & Bronè & 56 & Secondary & $\begin{array}{l}\text { Big } \\
\text { city }\end{array}$ & Married & $\begin{array}{l}\text { With } \\
\text { husband }\end{array}$ & Fertility issues \\
\hline 17 & Marija & 55 & $\begin{array}{l}\text { Secondary } \\
\text { (not finished } \\
\text { higher } \\
\text { education) }\end{array}$ & $\begin{array}{l}\text { Big } \\
\text { city }\end{array}$ & Single & Alone & $\begin{array}{l}\text { Circumstantial/no } \\
\text { partner }\end{array}$ \\
\hline 18 & Liucija & 62 & $\begin{array}{l}\text { Higher } \\
\text { education }\end{array}$ & $\begin{array}{l}\text { Big } \\
\text { city }\end{array}$ & Single & Alone & $\begin{array}{l}\text { Circumstantial/no } \\
\text { partner }\end{array}$ \\
\hline 19 & Veronika & 62 & $\begin{array}{l}\text { Higher } \\
\text { education }\end{array}$ & $\begin{array}{l}\text { Big } \\
\text { city }\end{array}$ & Single & Alone & $\begin{array}{l}\text { Circumstantial/no } \\
\text { partner }\end{array}$ \\
\hline 20 & Rasa & 50 & $\begin{array}{l}\text { Secondary } \\
\text { with } \\
\text { profession }\end{array}$ & $\begin{array}{l}\text { Small } \\
\text { city }\end{array}$ & Married & $\begin{array}{l}\text { With } \\
\text { husband }\end{array}$ & $\begin{array}{l}\text { Physiological } \\
\text { (miscarriages) }\end{array}$ \\
\hline 21 & Kotryna & 51 & Bachelor's & $\begin{array}{l}\text { Big } \\
\text { city }\end{array}$ & Single & Alone & $\begin{array}{l}\text { Circumstantial/no } \\
\text { partner }\end{array}$ \\
\hline
\end{tabular}

${ }^{a}$ As the education system has changed in Lithuania after independence in 1990, women who got their education earlier most often earned a higher education degree, not divided in bachelor's and master's degrees

\section{References}

Albertini, M., \& Kohli, M. (2009). What childless older people give: Is the generational link broken? Ageing \& Society, 29(8), 1261-1274.

Beck, U. (1993). The risk society. London: Sage.

Beck, U., \& Beck-Gernsheim, E. (2002). Individualization: Institutionalized individualism and its social and political consequences. London: Sage.

Demografijos metraštis 2017[Demographic Yearbook 2017]. 2018. Vilnius: Statistics Lithuania.

Dykstra, P. A., \& Hagestad, G. O. (2007). Childlessness and parenthood in two centuries. Different roads - different maps? Journal of Family Issues, 28(11), 1518-1532.

Evans, R., \& Holland, S. (2012). Community parenting and the informal safeguarding of children at neighbourhood level. Families, Relationships and Societies, 1(2), 173-190.

Ferland, P., \& Caron, S. L. (2013). Exploring the long-term impact of female infertility: A qualitative analysis of interviews with postmenopausal women who remained childless. The Family Journal: Counseling and Therapy for Couples and Families, 21(2), 180-188.

Gedvilaitė-Kordušienè, M., Tretjakova, V., \& Ubarevičienè, R. (2019). Bevaikystė Lietuvoje: tendencijos, normos ir teritorinè diferenciacija [Childlessness in Lithuania: Trends, norms and 
spatial differentiation]. STEPP: Socialine teorija, empirija, politika ir praktika/STEPP: Social theory, empirics, policy and practice, 18, 96-111.

Gedvilaitė-Kordušienè, M., Tretjakova, V., \& Krzyżowski, Ł. (2020). Women's feelings about childlessness in two pro-natalist countries. Polish Sociology Review, 2(210), 229-244.

Gibb, L. (2019). Reflections on my book. Childless Voices Women's History Review, 28, 1-3.

Giddens, A. (1991). Modernity and self-identity: Self and society in the late modern age. Cambridge: Polity.

Gillespie, R. (1999). Voluntary childlessness in the United Kingdom. Reproductive Health Matters, $7(13), 43-53$.

Graham, M., Hill, E., Shelly, J., \& Taket, A. (2013). Why are childless women childless? Findings from an exploratory study in Victoria, Australia. Journal of Social Inclusion, 4(1), 70-89.

Kanopienè, V, Mikulionienė, S., \& Česnuitytè, V. (2015). Lietuvos šeima Europos kontekste: monografija [Lithuanian family in the European context: Monograph]. Vilnius: Mykolas Romeris University.

Kessler, L. T. (2007). Community parenting. Washington University Journal of Law \& Policy, 24, 47-78.

Lebednykaitè, M. (2015). Apžadų prijuostèlès: meninès ypatybès ir paskirtis liaudiškojo pamaldumo praktikoje ['Vow aprons': artistic properties and function in the practice of folk piety]. Liaudies kultūra, 16(2), 65-82.

Letherby, G. (1999). Other than mothers as others: The experience of motherhood and nonmotherhood in relation to 'infertility' and 'involuntary childlessness'. Women's Studies International Forum, 22(3), 359-372.

Letherby, G. (2002). Challenging dominant discourses: Identity and change and the experience of 'infertility' and 'involuntary Childlessness'. Journal of Gender Studies, 11(3), 277-288.

Marcinkevičienè, D. (1999). Vienišas žmogus lietuvių kaimo bendruomenëje XIX a. - XX a. pradžioje [The singles in the Lithuanian village community at the turn of the century]. Liaudies kultūra, 1(64), 11-14.

Marcinkevičienè, D. (2008). Būti mama: vaikų priežiūros strategijos sovietinèje Lietuvoje 1945-1970 metais [Being the Mom. Childcare Strategies in Soviet Lithuania in 1945-1970]. Liaudies kultūra, 6(123), 31-39.

Marcinkevičienė, D., \& Praspaliauskienė, R. (1999). Moters įvaizdžio transformacija moterų spaudoje 1975-1997 [Transformations of woman's images in the Lithuanian press of 1975-1997]. Feminizmas, visuomene, kultūra, 1, 61-67.

Maslauskaitè, A. (2008). Moteru užimtumas ir lyčiu kultūra: lyginamoji Lietuvos ir Europos šaliu analizè, in Moterys, darbas, šeima, 26-56. Vilnius: Vilnius University Gender Studies Center.

Martin, S. P., \& Kendig, S. M. (2012). Childless women time with children: A focus on educational differences. Journal of Family Issues, 34(6), 828-853.

McCarthy, R., J. \& Edwards, R. (2011). Key concepts in family studies. SAGE Publications Ltd, https://www.doi.org/10.4135/9781446250990

Merz, E.-M., \& Liefbroer, A. C. (2012). The attitude toward voluntary childlessness in Europe: Cultural and institutional explanations. Journal of Marriage and Family, 74, 587-600.

Norkus, Z. (2008). Kokia demokratija, koks kapitalizmas? Pokomunistine transformacija Lietuvoje lyginamosios istorinès sociologijos požiüriu [Which democracy, which capitalism? Postcommunist transformation in Lithuania from the viewpoint of comparative historical sociology]. Vilnius: Vilnius University Publisher.

Pahl, R., \& Spencer, L. (2004). Personal communities: Not simply families of 'fate' or 'choice'. Current Sociology, 52(2), 199-221.

Pashos, A., \& McBurney, D. H. (2008). Kin relationships and the caregiving biases of grandparents, aunts, and uncles. A two-generational questionnaire study. Human Nature, 19(3), 311-330.

Pollet, T. V., \& Dunbar, R. I. M. (2008). Childlessness predicts helping of nieces and nephews in United States, 1910. Journal of Biosocial Science, 40(5), 761-770.

Pollet, T. V., Kuppens, T., \& Dunbar, R. I. M. (2006). When nieces and nephews become important: Differences between childless women and mothers in relationships with nieces and nephews. Journal of Cultural and Evolutionary Psychology, 4(2), 83-93.

Račiūnaitè, R. (2004). Krikščioniškosios vertybès lietuvių šeimos papročiuose [The Christian Values in the Customs of Lithuanian Family]. Soter, 13(41), 209-226. 
Sobotka, T. (2003). Re-emerging diversity: Rapid fertility changes in Central and Eastern Europe after the collapse of the communist regimes. Population, English Edition, 58(4-5), 451-486.

Sobotka, T. (2017). Childlessness in Europe: Reconstructing long-term trends among women born in 1900-1972. In M. Kreyenfeld \& D. Konietzka (Eds.), Childlessness in Europe: Contexts, causes, and consequences (pp. 17-53). Cham: Springer.

Stakuniene, V., \& Maslauskaite, A. (2008). Family transformations in the post-communist countries: Attitudes towards changes. In C. Höhn, D. Avramov, \& I. E. Kotowska (Eds.), People, population change and policies. Lessons from the population policy acceptance study (Vol. 1: Family change) (pp. 113-140). Dordrecht: Springer Science + Business Media B.V.

Tanskanen, A. O. (2015). Childlessness and Investment in nieces, nephews, aunts and uncles in Finland. Short report. Journal of Biosocal Science, 47(3), 402-406.

Van de Kaa, D. J. (1996). Anchored narratives: The story and findings of half a century of research into the determinants of fertility. Population Studies, 50(3), 389-432.

Venkatesan, S., \& Murali, C. (2019). 'Childless? Childfree? Neither, just ME': Pronatalism and (m)otherhood in Paula Knight's The Facts of Life. Journal of Graphic Novels and Comics, online first. https://doi.org/10.1080/21504857.2019.1617179

WHO. Indicators, Women of reproductive age (15-49 years) population (thousands). World Health Organization. https://www.who.int/data/maternal-newborn-child-adolescent/indicatorexplorer-new/mca/women-of-reproductive-age-(15-49-years)-population-(thousands). Accessed 13 Sept 2020.

Wirtberg, I., Möller, A., Hogström, L., Tronstad, S.-E., \& Lalos, A. (2007). Life 20 years after unsuccessful infertility treatment. Human Reproduction, 22(2), 598-604.

Yeshua-Katz, D. (2018). Childless in an IVF-nation: Online stigma-coping strategies in support groups for childless Israeli women. Information, Communication \& Society, 21(10), $1436-1452$.

Lina Šumskaitė defended her dissertation in sociology in 2014 entitled Fathering Practices of Men. She currently is a lecturer at Vilnius University in the Social Policy and Social Work programs. Her research interests include fathering and mothering practices, procreational intentions, and qualitative studies on childlessness.

Margarita Gedvilaitė-Kordušienė defended her dissertation in sociology in 2011 entitled Intergenerational Relationships and Their Determinants. She is currently an Assistant Professor at Vilnius Gediminas Technical University, and she works as a senior researcher at the Institute of Sociology at the Lithuanian Centre for Social Sciences. Her research is focused on family sociology and family demography, with a focus on intergenerational relations.

Open Access This chapter is licensed under the terms of the Creative Commons Attribution 4.0 International License (http://creativecommons.org/licenses/by/4.0/), which permits use, sharing, adaptation, distribution and reproduction in any medium or format, as long as you give appropriate credit to the original author(s) and the source, provide a link to the Creative Commons licence and indicate if changes were made.

The images or other third party material in this chapter are included in the chapter's Creative Commons licence, unless indicated otherwise in a credit line to the material. If material is not included in the chapter's Creative Commons licence and your intended use is not permitted by statutory regulation or exceeds the permitted use, you will need to obtain permission directly from the copyright holder.

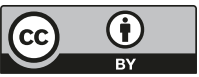

